\title{
Intratidal variability and transport of petroleum aromatic hydrocarbons in an anthropized tropical estuarine system: the Suape estuary (8.4S 35W)
}

\author{
Eliete Zanardi-Lamardo ${ }^{1 *}$, Carlos Augusto França Schettini ${ }^{1}$, Amanda Alves Vieira-Campos ${ }^{1}$, \\ Carolina Barbosa Cabral ${ }^{1}$, Marília S. Silva ${ }^{l}$
}

\author{
${ }^{1}$ Universidade Federal de Pernambuco \\ (Av. Arquitetura, s/n - Cidade Universitária - Recife - PE - 50740-550 - Brazil) \\ *Corresponding author: eliete.zanardi@gmail.com
}

\section{ABSTRACT}

The Suape Estuary encompasses the Suape Industrial Port Complex (SIPC), a major industrial development in Brazil's Northeast region, which, in order to be implanted, caused drastic environmental changes in this system. This study presents the first physical characterization of the Suape estuarine system, focusing on the local hydrodynamics, material transport and its influence on some specific properties. Physical properties were also associated to dissolved dispersed petroleum hydrocarbons (DDPHs). A study was undertaken during a complete semi-diurnal tidal cycle (13 hr), during which water level, water flow, current velocity and direction, water properties (salinity, temperature, suspended particulate matter - SPM -, chlorophyll and dissolved oxygen) were recorded using ADCP and CTD systems. The DDPHs were investigated in surface and bottom waters, by spectrofluorescence, using Carmópolis oil and chrysene as analytical standards. Results showed a well-mixed vertical structure, a semi-diurnal tide regime and a diurnal thermal pattern. There was no statistical difference between DDPH concentrations at surface and bottom, due to the tide acting as an important homogenizer. DDPHs were low and the main contribution seems to be that from SIPC, as the residual transport of DDPHs, chlorophyll and dissolved oxygen, was towards the Massangana estuary. An opposite pattern was observed for salinity and SPM, whose residual transport was towards the lagoon. The results pointed local hydrodynamics as an essential tool for understanding material transport and exchanges among the estuarine segments. A longer time series should be studied in order to obtain more robust conclusions.

Descriptors: DDPHs, Spectrofluorescence, Hydrodynamics, Salinity, Material transport, Port.

\section{Resumo}

A instalação do Complexo Industrial Portuário de Suape (CIPS) modificou algumas características físicas, químicas e biológicas do Estuário de Suape. Este estudo apresenta a primeira caracterização física deste sistema, focando na hidrodinâmica local, transporte de materiais e a influência destes sobre algumas propriedades locais. Os parâmetros físicos também foram associados aos hidrocarbonetos de petróleo dissolvidos e/ou dispersos (HPDDs). Durante um ciclo completo de maré $(13 \mathrm{~h})$, foram registrados o nível, fluxo e propriedades da água (salinidade, temperatura, material em suspensão - MS -, clorofila e oxigênio dissolvido), além da velocidade e direção das correntes, usando ADCP e CTD. Os HPDDs foram investigados nas águas superficiais e de fundo, através de espectrofluorescência. Os resultados revelaram uma estrutura vertical homogênea, um regime de maré semidiurno e um padrão térmico diurno. As concentrações de HPDDs na superfície e no fundo são baixas e similares, devido à ação da maré. A fonte mais provável é o CIPS, uma vez que o transporte residual dos hidrocarbonetos de petróleo, da clorofila e do oxigênio dissolvido são no sentido do estuário do Massangana. Um padrão oposto foi observado para o transporte residual da salinidade e MS, no sentido da lagoa. Estes resultados indicam que a hidrodinâmica local é essencial para entender o transporte e troca de materiais entre os vários segmentos do estuário. Estudos mais completos são necessários para se obter conclusões mais consistentes.

Descritores: HPDDs, Espectrofluorescência, Hidrodinâmica, Salinidade, Transporte de materiais, Porto. 


\section{INTRODUCTION}

Coastal regions are characterized by their high primary productivity and richness and abundance of species. The abundance of food, easy access for the transport of materials, natural protection from the open sea, among other factors, are highly advantageous for the economic development of coastal zones (González et al., 2006), which account for nearly $60 \%$ of all large urban centers (Zanardi-Lamardo et al., 2000). In many situations there is no planning of industrial and urban growth or for development of farming activities, whether of sugar-cane cultivation, cattle breeding, or aquaculture (CPRH, 2005). Such activities may contribute with various contaminants, including the polycyclic aromatic hydrocarbons (PAHs).

PAHs are widely distributed in the environment and have caused concern to government agencies, environmental researchers and even the general population, mainly due to their carcinogenic and teratogenic toxic effects (Baumard et al., 1998; Magi et al., 2002; Boonyatumanond et al., 2006; Chen et al., 2013; Rahmanpoor et al., 2014). They may be introduced directly into aquatic systems by the discharge of industrial and domestic effluents, fluvial runoff, oil spill accidents, shipping activities etc (Zaghden et al., 2007; Lemos et al., 2014). In addition, PAHs may be produced by the burning of oil and its derivatives and the incomplete combustion of biomass, reaching the marine environment through atmospheric deposition (Boehm, 2005; Meire et al., 2007; Lemos et al., 2014; Maciel et al., 2015a). Due to their hydrophobic characteristics, PAHs tend to be associated with suspended particulate matter (SPM), in accordance with its dynamics and subsequent deposition (Wang et al, 2001; Tolosa et al., 2004). SPM's dynamics in estuarine environments is rather complicated (Dyer, 1995; Winterwerp and Van Kesteren, 2004), since its presence in the water column depends on processes related to its cohesive properties (flocculation) and its interaction with the hydrodynamics. During a tidal cycle the currents will vary according to the tide, changing their intensity and direction, producing erosion during velocity peaks and allowing the particles to settle during quiescent waters. Their response to the hydrodynamics will determine the time the SPM, and the associated DDPHs, remain in the water column, and thus their transport.

The Suape estuarine system was a relatively wellpreserved environment until the early 1970s, from when it suffered major human induced changes similarly to many other small estuaries along Brazilian shores (Schettini et al., 2017). In order to overcome the problems related to the presence of the port of Recife inside the Recife Metropolitan Area, the Pernambuco State sought to create a new integrated port and industrial zone from scratch in the Suape estuary and its hinterland, the Suape Industrial Port Complex (SIPC; Figure 1). Today, there are more than one hundred companies in operation installed there, involved in diverse activities such as oil derivative transport and fuel distribution, with another 50 being implemented, amounting to total investments of about US\$ 17 billion (SUAPE, 2016). Activities in the SIPC have been very intense over the last two decades and the commerce of petroleum has been increasing due to the presence of the Abreu e Lima Refinery that became operational in December 2014. In the first semester of 2016 about 2.7 million tons of petroleum passed through Suape and, in July 2016, the refinery attained a new record, processing 100 thousand barrels of oil per day (SUAPE, 2016).

There is no doubt the SIPC leveraged the Pernambuco and neighboring states' economies. Nevertheless, to achieve this involved drastic transformations in the Suape estuarine system. A sizeable area of mangrove swamp was reclaimed, rivers were diverted, navigation channels dredged and the estuary's original overall geometry greatly modified (Figure 1, and further details in the Study Area section). Besides the profound changes in the estuary's functioning, especially in terms of the changes in its morphology and hydrodynamics (CONDEPE, 1983), a deterioration in its inherent water quality is to be expected as a result of the harbor activity, industrial effluents and eventual accidents, which may contribute to the introduction of oil into the system (Lemos et al., 2014).

In spite of its economic importance and related environmental concerns, there have so far been no investigations into the Suape estuarine circulation or the transport of properties. This study sought to present the first physical characterization of this system and investigated how hydrodynamics may influence material transport and exchanges between the different estuarine sectors with special emphasis on the analysis of the intratidal transport of petroleum hydrocarbons in the mangrove-fringed Massangana estuary.

\section{MATERIAL AND METHODS}

\section{STUDY AREA}

The Suape Estuarine System is located about $40 \mathrm{~km}$ south of the Recife Metropolitan Area, the capital of 
Pernambuco State, Brazil. The present estuarine area covers about $6 \mathrm{~km}^{2}$. Originally the area was bigger, formed by the confluence of the Massangana, Tatuoca, Ipojuca and Merepe Rivers in a coastal lagoon. The lagoon was separated from the ocean by a straight sandstone reef with a single inlet at the northern extremity (north inlet, Figure 1). During the installation of the SIPC, the central part of the lagoon was reclaimed, isolating the Ipojuca and Merepe in the southern part to which a new, wider and deeper, inlet was opened to permit the access of deeper draught ships into the inner harbor (south inlet, Figure 1); offshore jetties were also built in order to create a sheltered area for ship berths. The river flow in the northern lagoon was, therefore, reduced to that coming exclusively from the Massangana river, its hydrodynamics being thus completely altered (Paiva and Araújo, 2010). The harbor is on average $10 \mathrm{~m}$ deep, while the northern lagoon is 1-2 $\mathrm{m}$ deep, the Massangana's depths being up to as much as $6 \mathrm{~m}$.

The local annual mean air temperature is 25.5 ${ }^{\circ} \mathrm{C}$, ranging annually from 23.9 to 26.6 in August and February, respectively. The annual mean precipitation rate is 2,450 mm/year at the coast (Ramos et al., 2009), while the evapotranspiration rate is $1,500 \mathrm{~mm} /$ year (SRH$\mathrm{PE}, 2010)$. The rainy period is concentrated between March and July and shows greater inter-annual variability because it is strongly affected by the El Niño-Southern Oscillation (Andreoli and Kayano, 2007; Oliveira et al., 2011). There are no available river flow data, although it is to be expected that they will behave in accordance with the rainfall regime. The drainage area is of about 160 $\mathrm{km}^{2}$, and considering the water budget - comparing precipitation and evapotranspiration - an annual mean flow of about $5 \mathrm{~m}^{3} / \mathrm{s}$ is to be expected.

The regional tides are semi-diurnal and range between 1.5 and $3.5 \mathrm{~m}$ during the neap and spring tide periods, respectively (Schettini et al., 2016a). The shelf currents during summer are mainly southward while during winter they are mainly northward (Lira et al., 2010). There is no previous information about the estuary's circulation.

This area receives influence of several anthropogenic activities that could contribute with petroleum hydrocarbons, such as shipyard operation (hull paintings, ships docking, etc), contaminated sediments after dredging procedures, industrial discharges, some eventual releases of fuels or oil derivatives, and even atmospheric deposition of soot from industries and sugar cane burning (Lemos et al., 2014).

\section{FIELD SURVEY}

A field survey was carried out on November $25^{\text {th }}$, 2014, when water level, water flow, current velocities and direction, water properties (salinity, temperature, suspended particulate matter (SPM), chlorophyll and dissolved oxygen) and water samples were recorded/sampled during a complete semi-diurnal tidal cycle (13 hr). The survey started at 5:00 in the morning and finished at 18:00 in the evening, at high tide.

Water level and current velocity and direction were recorded with moored acoustic Doppler current profilers (ADCP) of the Nortek model Aquadopp Profiler of 1,000 $\mathrm{kHz}$. The ADCP were moored in the two channels which connected the Suape Lagoon to the harbor (\#E and \#W, in Figure 1). The ADCPs were set up to record data at 10 -minute intervals, where each values represents the average of 2 minutes at a $2 \mathrm{~Hz}$ sampling rate.

Water flow was recorded by an ADCP towed by an RDI model Workhorse of $1,200 \mathrm{kHz}$, undertaking a cross section of the lower stretch of the Massangana River (CS in Figure 1). Each water flow measurement was averaged over three consecutive passages. Positive flows were assigned as seaward, and negative flows landward.

Water salinity, temperature, SPM, chlorophyll and dissolved oxygen were recorded with a CTD probe by a JFE-Advantech model Rinko Profiler, at the center of the cross-section. The CTD was lowered at $1 \mathrm{~m} / \mathrm{s}$ speed, and as it records data at $10 \mathrm{~Hz}$, the vertical data resolution was of about $0.1 \mathrm{~m}$. Water flow and CTD casts were made at $0.5 \mathrm{hr}$ intervals.

\section{Petroleum Hydrocarbons}

Water samples were collected near ( $1 \mathrm{~m}$ below) the surface and near ( $1 \mathrm{~m}$ above) the bottom during a complete tide cycle (13 hours) at the CS point (Longitude: -34.9654 W and Latitude: -8.3589 S, Figure 1). Samples were taken in triplicate, every hour, with a $4 \mathrm{~L}$ amber glass bottle attached to a stainless steel frame. Immediately after sampling, $20 \mathrm{~mL}$ of $\mathrm{n}$-hexane was added to each sample, the bottle was manually agitated for 2 minutes, and a separating funnel was used to separate the organic extract from water (Lemos et al., 2014; Arruda-Santos et al., 2018). The extracts were frozen until laboratory analysis. During the sampling period, three field blanks were performed to assure there was no field contamination, adding the same solvent volume to a vial exposed to the local atmosphere. 
The extracts had sodium sulfate $\left(\mathrm{Na}_{2} \mathrm{SO}_{4}\right)$ added in order to remove any traces of water and concentrated to $10 \mathrm{~mL}$ in a rotary evaporator. Then the dissolved and/or dispersed petroleum hydrocarbons (DDPHs) were analyzed in a SpectraMax M3 Molecular Devices Spectrofluorimeter, with excitation at $310 \mathrm{~nm}$ and emission at $360 \mathrm{~nm}$ wavelengths (Knap et al., 1986; Zanardi et al., 1999a;b; Lemos et al., 2014; Arruda-Santos et al., 2018). The spectrofluorescence technique is a very simple and low cost methodology, but does not distinguish between individual compounds. On the other hand, it is very useful to identify the presence of aromatic hydrocarbons and how they change from place to place or even during a certain period of time. For this reason it has been used to identify hydrocarbon sources and help to understand material transport in aquatic environments.

The DDPHs were quantified based on two analytical curves prepared with an artificially weathered Brazilian crude oil from Carmópolis oil field and chrysene (Sigma-Aldrich, 99\% purity), and the results were expressed as equivalents of oil and chrysene, respectively. Chrysene has been used in various studies around the world (Atwood et al., 1987; Corbin, 1993; Kornilios et al., 1998; Nayar et al., 2004; Doval et al., 2006). Carmópolis oil comes from a large reserve in the Brazilian northeast: its composition is similar to that of several oils marketed in the area (ANP, 2015) and it is frequently used by Brazilian researchers in coastal and open water investigations (Zanardi et al.,1999a;b; Bícego et al., 2002; 2009; Lemos et al., 2014; Maciel et al., 2015b; Arruda-Santos et al., 2018 ). It is, therefore, interesting to report data quantified based on these two standards as this allows both regional (Carmópolis oil) and global (chrysene) comparisons. The concentration range used for the analytical curve was from 0 to 0.250 $\mu \mathrm{g} \mathrm{L}^{-1}$ for chrysene and the equation was $\mathrm{y}=11.553 \mathrm{x}$, $\mathrm{r}^{2}=0.9973$; and 0 to $1.25 \mu \mathrm{g} \mathrm{L}^{-1}$ for the Carmópolis oil with the equation $\mathrm{y}=5.6227 \mathrm{x}, \mathrm{r}^{2}=0.9999$. In both cases, the intercept was kept at zero.

The averages of the fluorescence signals from the blanks were subtracted from each sample and the detection limit (DL) was considered as three times the standard deviation of blank results (Quevauviller et al., 1992). The calculated DLs were $0.01 \mu \mathrm{g} . \mathrm{L}^{-1}$ and $0.02 \mu \mathrm{g} . \mathrm{L}^{-1}$, expressed in chrysene and Carmópolis oil equivalents, respectively.

\section{STATISTICAL ANALYSES}

Data normality was checked using the KolmogorovSmirnov test and the t-student test was applied for investigating the differences between DDPH concentrations in superficial and bottom waters and other parameters. The critical level of significance was set at 0.05 for all tests. Statistical analyses were performed using BioEstat 5.0 software.

\section{RESULTS AND DISCUSSION}

The survey started and ended at high tide. The measured tidal range was $1.98 \mathrm{~m}$ (Figure 2), and the tidal range predicted, for Suape Port, by the Brazilian Navy was 1.9 $\mathrm{m}$. This range characterizes the local spring tide condition. The instantaneous water flow at the Massangana cross section ranged between 544 and $-516 \mathrm{~m}^{3} \mathrm{~s}^{-1}$. The tide stage diagram indicates that the tidal wave behaves as a mixed wave, of a progressive nature at high water, when the flood is at a maximum, but a standing wave at low water, when the flow is null (Figure 2). The integral of the instantaneous water flow during the flood or ebb phase provides the tidal prism, the volume that is exchanged with the adjacent water body during the tidal cycle (Kjerfve, 1990). The tidal prism was $6.98 \times 10^{6} \mathrm{~m}^{3}$. The channels' volume exchange can be calculated by the product of the tidal range and the channels' area $\left(1.42 \mathrm{~km}^{2}\right)$, which gives $2.81 \times 10^{6} \mathrm{~m}^{3}$, or $40 \%$ of the tidal prism. The remaining volume is the one that floods the mangrove flats during high tide. This means that a large fraction of the water which flows landwards floods the mangrove swamps which are depositional areas for the SPM (Wolanski and Ridd, 1986).

The water volume which passes through the Massangana cross-section during the flood comes from the Suape lagoon, which, in its turn, can be exchanged with the adjacent sea through both north and south inlets. Figure 3 shows the time series of the current velocity in the east and west channels. The currents present similar behavior and similar range, from - 0.6 to $0.4 \mathrm{~m} / \mathrm{s}$ during flood and ebb, respectively. Flood means water flowing from the harbor into the lagoon, and ebb means the opposite. The residual currents were -0.14 and $-0.10 \mathrm{~m} / \mathrm{s}$ in the east and west channels, respectively. This finding indicates a residual flow from the harbor to the lagoon, which can be explained by the inlet's geometry. The south inlet being wider and deeper presents less resistance (friction) to the tidal flow, allowing the tide easier transit than does the north inlet. 


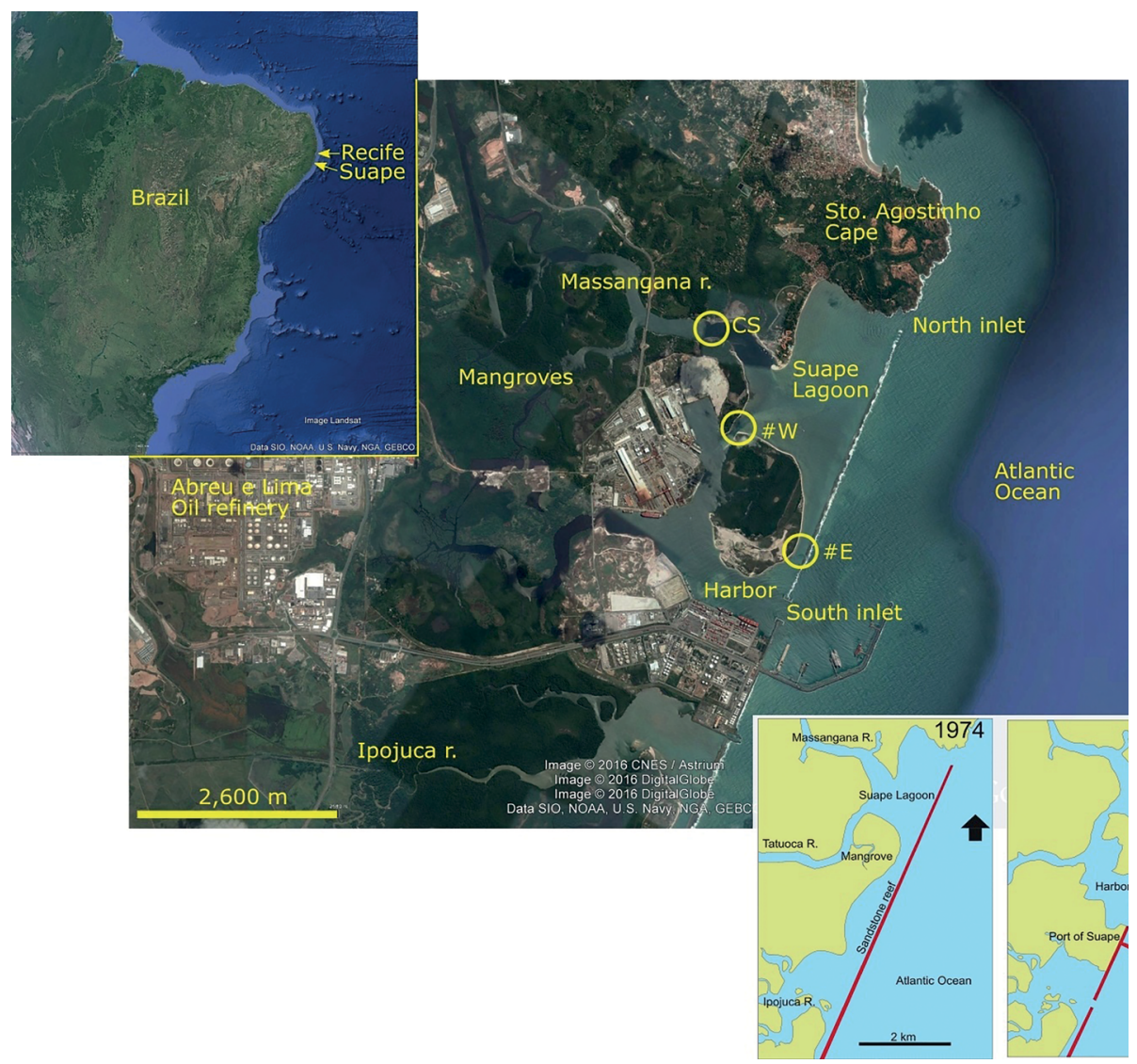

Figure 1. Localization of the Suape Estuarine System (SES) on the Brazilian coast (upper left); details of the SES with indication of the sampling points (CS, \#W and \#E) and the main local features (center); sketch of the pre and post Suape Port installation (lower right).

The temporal and vertical distributions of salinity, temperature, SPM, chlorophyll and dissolved oxygen saturation are shown in Figure 4. The salinity ranged between 36 and 36.8 psu, with a mean value of $36.5 \pm 0.28$ psu (Figure 4A). The minimum values were recorded at low water and the maxima at high water, indicating a small dilution from the local freshwater inflow. The vertical salinity distribution was well mixed, with a weak stratification occurring during the flood. The temperature ranged between 27.5 and $29.2^{\circ} \mathrm{C}$, with a mean value of $28.2 \pm 0.52$ ${ }^{\circ} \mathrm{C}$ (Figure 4B). The minimum values were recorded at the beginning of the campaign, and the maximum at $15 \mathrm{hr}$, indicating a diurnal thermal pattern.

The SPM presented a narrow range of variation, between 19 and $28 \mathrm{mg} \mathrm{L}^{-1}$, with a mean value of $22.2 \pm 2.80 \mathrm{mg} \mathrm{L}^{-1}$ (Figure $4 \mathrm{C}$ ). The minimum values were recorded at both high water episodes, and the maximum values were recorded during the ebb. There is also a less pronounced increase in SPM near the bottom during the flood. The slightly higher concentration during the ebb, and the minor degree during the flood, suggest that the origin of the SPM is the erosion of the bed during the current peaks. The chlorophyll ranged between 0.7 and $2.7 \mu \mathrm{g} \mathrm{L}{ }^{-1}$, with a mean value of $1.5 \pm 0.52 \mu \mathrm{g} \mathrm{L}^{-1}$ (Figure 4D). The maximum values were recorded at low tide and the beginning of the flood. The dissolved oxygen saturation ranged between 65 and $100 \%$ with a mean value of $87 \pm 11 \%$ (Figure 4D). The minimum values were recorded at low water and the maximum values during the flood, at $15 \mathrm{hr}$.

The DDPH average concentrations in the surface samples ranged from $0.02 \pm 0.00$ to $0.11 \pm 0.04 \mathrm{mg} \mathrm{L}^{-1}$ Carmópolis oil equiv. and $0.01 \pm 0.00$ to $0.05 \pm 0.02 \mathrm{mg} \mathrm{L}^{-1}$ chrysene equiv. (Table 1). At the bottom, the concentrations were $<\mathrm{DL}$ to $0.10 \pm 0.02 \mathrm{mg} \mathrm{L}^{-1}$ Carmópolis oil equiv. and $<$ DL to $0.05 \pm 0.01 \mathrm{mg} \mathrm{L}^{-1}$ chrysene equiv. (Table 1). The concentrations expressed in chrysene equivalents were always $51 \%$ lower than those expressed in Carmópolis oil equivalents. Therefore, the discussion will be presented based only on the Carmópolis data. The relative standard deviation ( $\mathrm{RSD}=$ standard deviation/mean) of the triplicates was calculated and $96 \%$ of the samples 


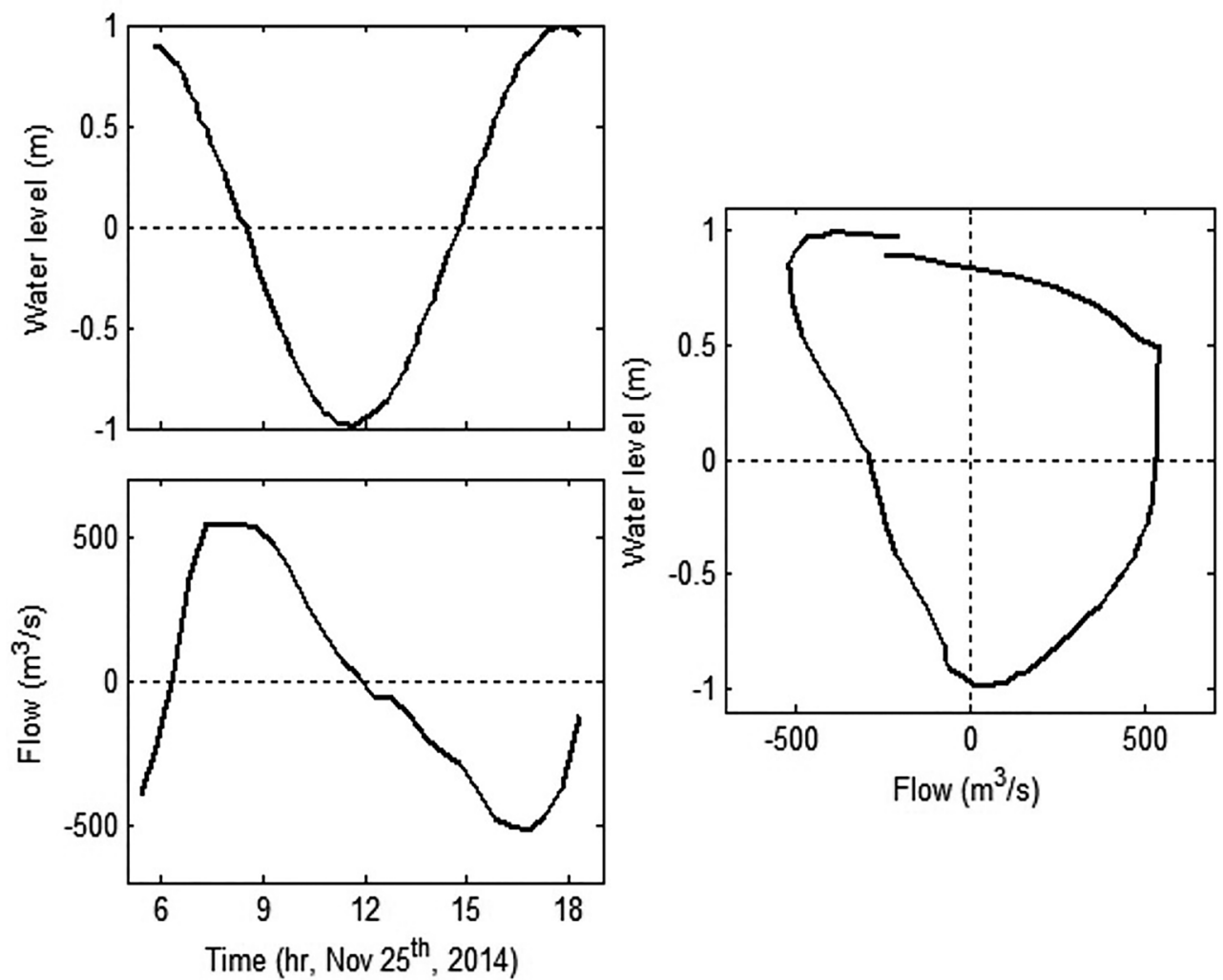

Figure 2. Time series of water level (left, top panel) and water flow (left, bottom panel) and the tide stage diagram (right panel) for the Massangana cross section, Suape estuary. November $25^{\text {th }}, 2014$.

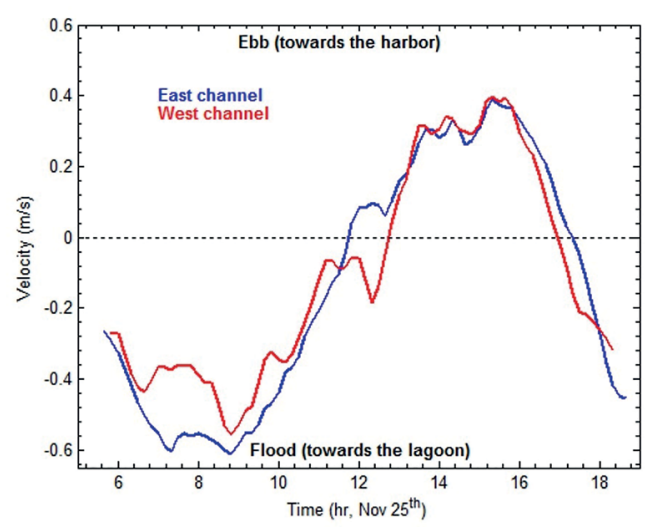

Figure 3. Time series of current velocity in east (blue) and west (red) channels. Suape estuary, November $25^{\text {th }}, 2014$.

were within $6 \%$ to $49 \%$, implying acceptable variability during the procedures (Knap et al., 1986; Zanardi et al., 1999b; Bícego et al., 2002; Lemos et al., 2014).

The minimum values were recorded at high water and the maximum at low water (Figure 5), indicating a small dilution of the marine water inflow, as observed previously in the Capibaribe Estuarine System, an urbanized estuary in Pernambuco (Favrod, 2012; Cabral, 2014). An exception was observed at the very beginning of the campaign, where higher concentrations were observed at high water (Figure 5). This could be an indication of the residual contribution from the Port of Suape which came through the Suape lagoon. A previous study in this area reported higher DDPH concentrations at the Suape Port and Atlântico Sul shipyard than in the Massangana river area (Lemos et al., 2014). The authors related the highest concentrations to oil and fuels released by ships and to shipping activities and dredging operations that might remobilize pollutants from the resuspended material to the water column, among others.

The data normality was tested using the KomolgorovSmirnov test. There was no statistical difference (t-Student, $\alpha=0.05$ ) between DDPH concentrations in superficial and bottom waters $(\mathrm{t}=0.2114, p=0.8342)$, which is to be expected considering the vertical distributions of the other scalars, mainly salinity which indicates a well-mixed pattern. The DDPH concentration was not correlated to 


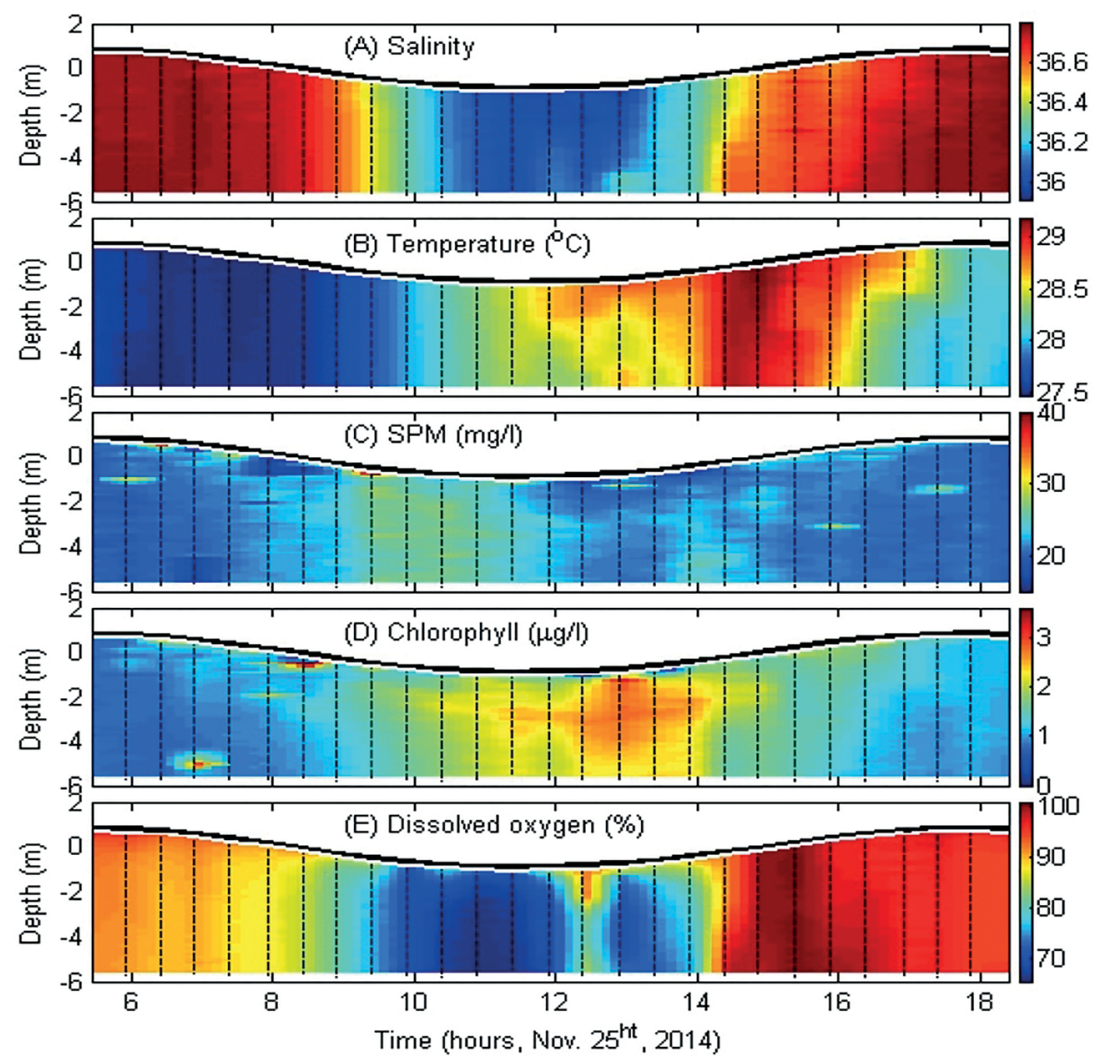

Figure 4. Vertical and temporal distributions of salinity (A), temperature (B), SPM (C), chlorophyll (D) and dissolved oxygen saturation (E) at the Massangana cross-section, Suape estuary. November $25^{\text {th }}, 2014$.

Table 1. DDPH concentrations and Standard Deviation expressed in $\mu \mathrm{g} \mathrm{L}^{-1}$ Carmópolis oil and chrysene equivalents, in surface and bottom waters at the Massangana cross-section, Suape estuary. November $25^{\text {th }}, 2014$.

\begin{tabular}{|c|c|c|c|c|c|c|c|c|c|c|c|c|}
\hline \multirow{4}{*}{$\begin{array}{l}\text { Sampling } \\
\text { Time (h) } \\
5: 30\end{array}$} & \multicolumn{6}{|c|}{ Carmópolis oil } & \multicolumn{6}{|c|}{ Chrysene } \\
\hline & \multirow{2}{*}{\multicolumn{3}{|c|}{$\begin{array}{l}\text { Surface } \\
\mu \mathrm{g} \mathrm{L}^{-1}\end{array}$}} & \multirow{2}{*}{\multicolumn{3}{|c|}{$\begin{array}{l}\text { Bottom } \\
\mu \mathrm{g} \mathrm{L}^{-1}\end{array}$}} & \multirow{2}{*}{\multicolumn{3}{|c|}{$\begin{array}{l}\text { Surface } \\
\mu \mathrm{g} \mathrm{L}^{-1}\end{array}$}} & \multirow{2}{*}{\multicolumn{3}{|c|}{$\begin{array}{c}\text { Bottom } \\
\mu \mathrm{g} \mathrm{L}^{-1}\end{array}$}} \\
\hline & & & & & & & & & & & & \\
\hline & 0.11 & \pm & 0.04 & 0.10 & \pm & 0.02 & 0.05 & \pm & 0.02 & 0.05 & \pm & 0.01 \\
\hline $6: 30$ & 0.04 & \pm & 0.00 & 0.06 & \pm & 0.01 & 0.02 & \pm & 0.00 & 0.03 & \pm & 0.00 \\
\hline $7: 30$ & 0.02 & \pm & 0.00 & 0.05 & \pm & 0.02 & 0.01 & \pm & 0.00 & 0.04 & \pm & 0.03 \\
\hline $8: 30$ & 0.02 & \pm & 0.01 & 0.06 & \pm & 0.01 & 0.01 & \pm & 0.00 & 0.03 & \pm & 0.01 \\
\hline $9: 30$ & 0.03 & \pm & 0.01 & 0.10 & \pm & 0.03 & 0.01 & \pm & 0.00 & 0.05 & \pm & 0.01 \\
\hline $10: 30$ & 0.04 & \pm & 0.03 & 0.04 & \pm & 0.01 & 0.02 & \pm & 0.01 & 0.02 & \pm & 0.00 \\
\hline $11: 30$ & 0.07 & \pm & 0.03 & 0.05 & \pm & 0.02 & 0.03 & \pm & 0.01 & 0.02 & \pm & 0.01 \\
\hline $12: 30$ & 0.05 & \pm & 0.01 & 0.03 & \pm & 0.00 & 0.02 & \pm & 0.01 & 0.01 & \pm & 0.00 \\
\hline $13: 30$ & 0.11 & \pm & 0.04 & 0.07 & \pm & 0.03 & 0.05 & \pm & 0.02 & 0.03 & \pm & 0.01 \\
\hline $14: 30$ & 0.06 & \pm & 0.03 & 0.03 & \pm & 0.00 & 0.03 & \pm & 0.01 & 0.01 & \pm & 0.00 \\
\hline $15: 30$ & 0.06 & \pm & 0.02 & 0.05 & \pm & 0.02 & 0.03 & \pm & 0.01 & 0.03 & \pm & 0.01 \\
\hline $16: 30$ & 0.04 & \pm & 0.00 & 0.03 & \pm & 0.01 & 0.02 & \pm & 0.00 & 0.02 & \pm & 0.00 \\
\hline $17: 30$ & 0.05 & \pm & 0.01 & $<\mathrm{DL}$ & & & 0.02 & \pm & 0.01 & $<\mathrm{DL}$ & & \\
\hline $18: 30$ & 0.05 & \pm & 0.01 & 0.04 & \pm & 0.00 & 0.02 & \pm & 0.01 & 0.02 & \pm & 0.00 \\
\hline
\end{tabular}

$<\mathrm{DL}=$ below detection limit 


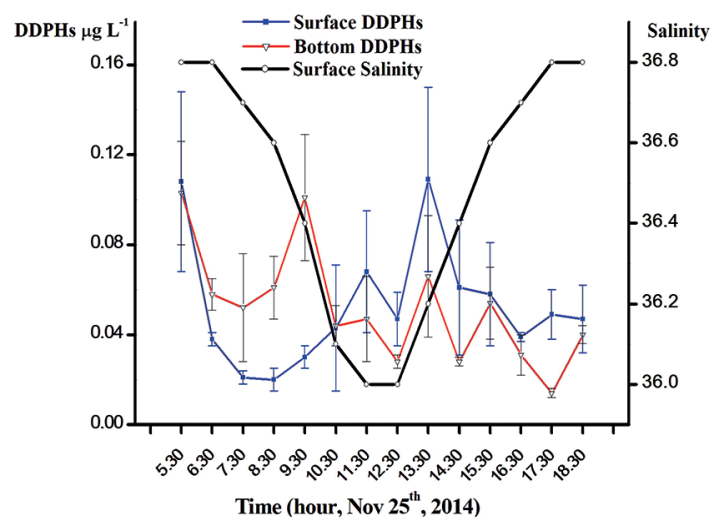

Figure 5. Temporal distribution of Salinity and DDPHs (concentration \pm Std Dev in $\mathrm{mg} \mathrm{L}^{-1}$ Carmópolis oil equiv.) in surface waters at the Massangana cross-section, Suape estuary. November $25^{\text {th }}, 2014$.

salinity either at the surface $(\mathrm{r}=-0.2319, p=0.425)$ or at the bottom $(\mathrm{r}=0.26, \mathrm{p}=0.3694)$, nor to SPM at the surface $(\mathrm{r}=$ $0.41, p=0.14)$ or at the bottom $(\mathrm{r}=0.17, p=0.53)$. The lack of correlation of DDPH concentrations to salinity can be explained by the very small salinity range recorded along the tidal cycle $(<1 \mathrm{psu})$. The salinity difference between high and low water was less than 1 psu with the smaller values recorded at low water. This indicates very low spatial gradients and very low fresh water inflow. On other words, the sampled conditions do not allow to identify a possible continental source which could be associated with freshwater, and the prevailing marine conditions indicates only the transit of substances locally.

The lack of correlation of DDPHs to SPM concentration results from the same cause, i.e., the very low range of SPM variation recorded along the tidal cycle $\left(\sim 10 \mathrm{mg} \mathrm{L}^{-1}\right)$. In comparative terms, low SPM concentrations have been reported during the dry season for other tropical estuaries such as that of the Capibaribe, Pernambuco State (Schettini et al., 2016b) and of the Caravelas, Bahia State (Schettini and Miranda, 2010). Together with the very slight freshwater dilution, this supports the hypothesis that much of the SPM in the water column is due to local reworking (erosion, transport and deposition) in the estuarine basin.

The present study observed very low DDPH concentrations as compared to other estuaries in Pernambuco State (Table 2) and other estuarine systems around the world (Law, 1981; Salíhog̈lu et al., 1987; Wattayakorn et al., 1998; Zanardi et al., 1999a;b; Bícego et al., 2002; Nayar et al., 2004). These low levels probably reflect the tidal action and local hydrodynamics that contribute to contaminants dispersion, and they do not represent a significant contamination, being considered at a baseline level (Lemos et al., 2014).

Further of describing the intertidal variability of the water properties in a tide-dominated environment, it is always insightful to investigate the residual transport of these properties. Estuaries that receive a sizeable volume of freshwater will, by simple mass conservation, pass on the same volume. However, as the water flows through the system it will be subjected to tidal action, and mixing will take place, leading to more complex fresh-salt water interactions. Consequently, most estuaries function as efficient traps rather than sources for the coastal seas (Schubel and Carter, 1984). In systems experiencing low inflow of freshwater, as in the present case, the trapping efficiency may even be enhanced.

The semi-diurnal tidal cycle has a period of $12.4 \mathrm{hr}$, and as the tidal signal has a nearly sinusoidal shape, the values at times zero and 12.4 are in phase and must be the same. Thus, the residual water flow can be calculated by time-averaging the flow over 12-hr windows. The survey lasted for 13 hours and the water flow was sampled at $0.5 \mathrm{hr}$ intervals, resulting in three 12-hr windows, which can be averaged too. The residual water flow obtained was $0.2 \mathrm{~m}^{3} \mathrm{~s}^{-1}$. This value is very low and fits the present hydrological situation of the estuary (the dry season), although it is also within

Table 2. DDPH concentrations ( $\mu \mathrm{g} \mathrm{L}^{-1}$ Carmópolis oil equiv.) in different estuaries of Pernambuco, Northeastern Brazil.

\begin{tabular}{lcc}
\hline Study area & DDPH range $\left(\mu \mathrm{g} \mathrm{L}^{-1}\right)$ & Authors \\
\hline Suape estuarine system (Aug/2011; Feb/2012) & $0.05-4.59$ & Lemos et al. (2014) \\
Capibaribe Estuarine System (Nov/Dec, 2011) & $0.33-7.41$ & Favrod (2012) \\
Capibaribe Estuarine System (Sept/Oct, 2013) & $0.20-3.65$ & Maciel et al. (2015) \\
Capibaribe estuarine system (May/2014) & $0.47-5.63$ & Santos (2015) \\
Santa Cruz Channel (Jul/2013) & $0.23-0.37$ & Arruda-Santos et al. (2018) \\
Goiana estuarine system (Dec/2015) & $0.20-0.51$ & Present study \\
Suape estuarine system (Nov/2014 - Steady station) & $0.01-0.11$ & \\
\hline
\end{tabular}


the error limits of the sampling procedure. Nevertheless, it suggests the sampling was efficient to cover the tidal water exchange between the estuary and the lagoon. A high value for the residual flow, positive or negative, would indicate a major sampling error.

As we are reasonably confident the sampling captured the water budget accurately, we calculated the residual transport of salinity, SPM, chlorophyll and dissolved oxygen in the same fashion. As the DDPHs were sampled hourly, there are two 12-hr windows instead of three. First, the instantaneous transport was calculated by the product of the scalar to the flow, then the residual transport was calculated as described above. For transport purposes and dimensional correctness, salinity concentration was understood as being $\mathrm{g} \mathrm{kg}^{-1}$ (IOC, 2010), and its transport must also be calculated by the product of the water density. The residual transports are: salinity $=213 \mathrm{~kg} \mathrm{~s}^{-1} ; \mathrm{SPM}=0.31 \mathrm{~kg} \mathrm{~s}^{-1}$; chlorophyll $=-16.5 \times 10^{-6} \mathrm{~kg} \mathrm{~s}^{-1}$; dissolved oxygen $=-0.12 \mathrm{~kg} \mathrm{~s}^{-1}$; and DDPHs $=-0.9 \times 10^{-6} \mathrm{~kg} \mathrm{~s}^{-1}$.

Longer time series would be required to obtain more robust values for residual transport (Lerczak et al., 2006; Schettini et al., 2013), although the present data are valuable for future reference. Even more important than the values themselves, are the directions of the transport. Salinity and SPM residual transports were towards the lagoon, while chlorophyll, dissolved oxygen and DDPHs were towards the estuary. Concerning the SIPC as being the potential source of DDPHs, the general circulation in the Suape estuarine system and the residual transport in the Massangana, the estuary may works as a potential sink for this material.

\section{CONCLUSION}

This study presents the first physical characterization of the Suape estuarine system and shows the importance of the local hydrodynamics for the understanding of the material transport and exchanges among the estuarine segments. This system presents a well-mixed vertical structure, a semi-diurnal tide regime and a diurnal thermal pattern. The residual transport of salinity and SPM was towards the lagoon but a reverse pattern was registered for chlorophyll, dissolved oxygen and petroleum hydrocarbons, whose residual direction was towards the estuary. No clear relationship between DDPHs and physical variables were found. Petroleum hydrocarbons are at a baseline level but the SIPC seems to be a potential contributor of DDPHs to the area.
Continuous monitoring is preeminent considering that the Massangana mangrove swamps were seen to be a potential sink for this material.

\section{AKNOWLEDGMENTS}

The authors gratefully thank the CNPq (482494/20123) and FACEPE/FAPESP (APQ-0074-1.08/11) for their financial support for this project and the Research Support Foundation of the State of São Paulo (FAPESP/FACEPE/ ANR 2011/50582-0) for the cooperation activities developed in scope of the thematic project. CAFS thanks CNPq for the Scholarship granted (201604/2015-9) and AAVC and $\mathrm{CBC}$ for the Graduate Research Fellowship. The authors would further thank Nykon Craveiro and Vanessa Moraes for their assistance with the sampling.

\section{REFERENCES}

ARRUDA-SANTOS, R. H., SCHETTINI, C. A., YOGUI, G. T., MACIEL, D. C. \& ZANARDI-LAMARDO, E. 2018. Sources and distribution of aromatic hydrocarbons in a tropical marine protected area estuary under influence of sugarcane cultivation. Science of The Total Environment, 624, 935-944. DOI: 10.1016/j.scitotenv.2017.12.174

ANDREOLI, R.V. \& KAYANO, M. T. 2007. A importância relativa do atlântico tropical sul e pacífico leste na variabilidade de precipitação do Nordeste do Brasil. Revista Brasileira de Meteorologia, 22, 63-74.

ANP (Agência Nacional do Petróleo, Gás Natural e Biocombustíveis). 2015. Plano de Desenvolvimento Aprovado. Carmópolis: Reunião de Diretoria n ${ }^{\circ}$ 800, Resolução n 273/2015.

ATWOOD, D. K., BURTON, F. J., CORREDOR, J. E., HARVEY, G. R., MATA-JIMENEZ, A. J., VASQUEZ-BOTELLO, A. \& WADE, B. A. 1987. Results of the CARIPOL petroleum pollution monitoring project in the wider Caribbean. Marine Pollution Bulletin, 18, 540-548.

BAUMARD, P., BUDZINSKI, H. \& GARRIGUES, P. 1998. Polycyclic aromatic hydrocarbons in sediments and mussels of the western Mediterranean sea. Environmental Toxicology and Chemistry, 17, 765-776. DOI: 10.1002/etc.5620170501

BÍCEGO, M. C., ZANARDI-LAMARDO, E., TANIGUCHI, S., MARTINS, C. C., SILVA, D. A. M., SASAKI, S. T., ALBERGARIA-BARBOSA, A. C. R., PAOLO, F. S., WEBER, R. R. \& MONTONE, R. S. 2009. Results from a 15-year study on hydrocarbon concentrations in water and sediment from Admiralty Bay, King George Island, Antarctica. Antarctic Science, 21, 209-220.

BÍCEGO, M. C., ZANARDI-LAMARDO, E., TANIGUCHI, S. \& WEBER, R. R. 2002. Natural levels of dissolved/dispersed petroleum hydrocarbons in the South West Atlantic. Marine Pollution Bulletin, 44, 1166-1169.

BOEHM, P. D. 2005. Polycyclic Aromatic Hydrocarbons (PAHs). In: MORRISON, R. D., MURPHY, B. L. (eds.) Environmental Forensics. Burlington: Academic Press.

BOONYATUMANOND, R., WATTAYAKORN, G., TOGO. A. \& TAKADA. H. 2006. Distribution and origins of polycyclic 
aromatic hydrocarbons (PAHs) in riverine, estuarine, and marine sediments in Thailand. Marine Pollution Bulletin, 52, 942-956. DOI: http://dx.doi.org/10.1016/j.marpolbul.2005.12.015.

CABRAL, C. B. 2014. Variabilidade longitudinal e mareal das concentrações de hidrocarbonetos de petróleo no estuário do Rio Capibaribe. Completion of Course Work - Bachelor of Biological/Environmental Sciences. Universidade Federal de Pernambuco.

CHEN, C. F., CHEN, C. W., DONG, C. D. \& KAO, C. M. 2013. Assessment of toxicity of polycyclic aromatic hydrocarbons in sediments of Kaohsiung Harbor, Taiwan. Science of Total Environment, 463-464, 1174-1181. DOI: http://dx.doi. org/10.1016/j.scitotenv.2012.06.101.

CONDEPE (Instituto de Desenvolvimento de Pernambuco). 1983. Caracterização do complexo estuarino-lagunar da área de Suape (Pernambuco-Brasil). Recife, CONDEPE.

CORBIN, C. J. 1993. Petroleum contamination of the coastal environment of St. Lucia. Marine Pollution Bulletin, 26, 579580.

CPRH (Agência Estadual de Meio Ambiente e Recursos Hídri$\cos )$. 2005. Relatório de monitoramento de bacias hidrográficas do Estado de Pernambuco. [cited 2018 Mar 7]. Recife. Available from: http://www.cprh.pe.gov.br

DOVAL, M. D., MOROÑO, A., PAZOS, Y., LOPEZ, A., MADRIÑÁN, M., CABANAS, J. M. \& MANEIRO, J. 2006. Monitoring dissolved aromatic hydrocarbon in Rias Baixas embayments (NW Spain) after Prestige oil spills: Relationship with hydrography. Estuarine, Coastal and Shelf Science, 67, 205-218.

DYER, K. R. 1995. Sediment transport processes in estuaries. In: PERILLO, G. M. E. (ed.) Geomorphology and sedimentology of estuaries. New York: Elsevier.

FAVROD, N. 2012. Determinação de hidrocarbonetos do petróleo dissolvidos elou dispersos nas águas do Complexo Estuarino da Bacia do Pina - Bacia Portuária (Porto de Recife). Completion of Course Work - Bachelor of Biological / Environmental Sciences. Universidade Federal de Pernambuco.

GONZÁLEZ, J. J., VIÑAS, L., FRANCO, M. A., FUMEGA, J., SORIANO, J. A., GRUEIRO, G., MUNIATEGUI, S., LÓPEZ-MAHÍA, P., PRADA, D., BAYONA, J. M., ALZAGA, R. \& ALBAIGÉS, J. 2006. Spatial and temporal distribution of dissolved/dispersed aromatic hydrocarbons in seawater in the area affected by the Prestige oil spill. Marine Pollution Bulletin, 53, 250-259.

IOC, SCOR and IAPSO. 2010. The international thermodynamic equation of seawater - 2010: Calculation and use of thermodynamic properties. Intergovernmental Oceanographic Commission, Manuals and Guides No. 56, Paris, UNESCO.

KJERFVE, B. 1990. Manual for investigation of hydrological processes in mangrove ecosystems, Paris, UNESCO/UNDP.

KNAP, A. H., BURNS, K. A., DAWSON, R., EHRHARDT, M. \& PALMORK, K, S. 1986. Dissolved/dispersed hydrocarbons, tarballs and the surface microlayer: Experiences from an IOC/UNEP Workshop in Bermuda, December, 1984. Marine Pollution Bulletin, 17, 313-319.

KORNILIOS, S., DRAKOPOULOS, P.G. \& DOUNAS, C. 1998. Pelagic tar, dissolved/dispersed petroleum hydrocarbons and plastic distribution in the Cretan Sea, Greece. Marine Pollution Bulletin, 36, 989-993.
LAW, R. J. 1981. Hydrocarbon concentrations in water and sediments from UK marine waters, determined by fluorescence spectroscopy. Marine Pollution Bulletin, 12, 153-157.

LEMOS, R. T. O., CARVALHO, P. S. M. \& ZANARDI-LAMARDO, E. 2014. Petroleum hydrocarbons in water from a Brazilian tropical estuary facing industrial and port development. Marine Pollution Bulletin, 82, 183-188.

LERCZAK, J. A., GEYER, W. R. \& CHANT, R. J. 2006. Mechanisms driving the time-dependent salt flux in a partially stratified estuary. Journal of Physical Oceanography, 36, 2296-2311.

LIRA, L., WOR, C., HAZIN, F. H. V., BRAGA JÚNIOR, H. A. C. \& SANTOS, J. C. P. 2010. Estudo de correntes marinhas por meio de lançamento de cartões de deriva no litoral do estado de Pernambuco, Brasil. Arquivos de Ciências do Mar, 43, 30-37.

MACIEL, D.C., DE SOUZA, J.R.B., TANIGUCHI, S., BÍCEGO, M.C., ZANARDI-LAMARDO, E. 2015a. Sources and distribution of polycyclic aromatic hydrocarbons in a an urbanized tropical estuary and adjacent shelf, Northeast of Brazil. Mar. Pollut. Bull. 101, 429-433. doi:10.1016/j.marpolbul.2015.09.051.

MACIEL, D. C., COSTA, B. V. M., SANTOS, L. P. S., SOUZA, J. R. B. \& ZANARDI-LAMARDO, E. 2015b. Avaliação da toxicidade dos sedimentos do Sistema Estuarino do Capibaribe (Pernambuco, Brasil) utilizando o copépodo bentônico Tisbe biminiensis Volkmann Rocco (1973). Tropical Oceanography, 43, 26-37. DOI: 10.5914/1679-3013.2015.0119

MAGI, E., BIANCO, R., IANNI, C. \& DI CARRO, M. 2002. Distribution of polycyclic aromatic hydrocarbons in the sediments of the Adriatic Sea. Environmental Pollution, 119, 9198. DOI: http://dx.doi.org/10.1016/S0269-7491(01)00321-9

MEIRE, R. O., AZEREDO, A. \& TORRES, J. P. M. 2007. Aspectos ecotoxicológicos de hidrocarbonetos policíclicos aromáticos. Oecologia Brasiliensis, 11, 188-201.

NAYAR, S., GOH, B. P. L. \& CHOU, L. M. 2004. The impact of petroleum hydrocarbons (diesel) on periphyton in an impacted tropical estuary based on in situ microcosms. Journal of Experimental Marine Biology and Ecology, 302, 213-232.

OLIVEIRA, G. C. S., SILVA JUNIOR, J. P., NÓBREGA, R. S. \& GIRÃO, O. 2011. Uma abordagem da geografia do clima sobre eventos extremos de precipitação em Recife-PE. Revista Brasileira de Geografia Física, 2, 238-251.

PAIVA, A. C. G. \& ARAÚJO, M. E. 2010. Environmental characterization and spatial distribution of fish fauna in estuaries in the State of Pernambuco, Brazil. Tropical Oceanography, v. $38,1-46$

QUEVAUVILLER, P, COFINO, W., VIJVERBERG, F., D. E. WELLS, D. E. \& GRIEPINK, B. 1992. Quality assurance in marine monitoring. EUR Report, 14297, Luxembourg, Commission of the European Communities.

RAHMANPOOR, S., GHAFOURIAN, H., HASHTROUDI, S. M. \& BASTAMI, K. D. 2014. Distribution and sources of polycyclic aromatic hydrocarbons in surface sediments of the Hormuz strait, Persian Gulf. Marine Pollution Bulletin, 78, 224-229. DOI: http://dx.doi.org/10.1016/j.marpolbul.2013.10.032

RAMOS, A. M., SANTOS, L. A. R. \& FORTES, L. T. G. 2009. Normas Climatólogicas do Brasil 1961-1990, Brasília, Instituto Nacional de Meteorologia-INMET. 
SALİHOG̈LU I., SAYDAM, C. \& YILMAZ, A. 1987. Long term impact of dissolved dispersed petroleum hydrocarbons (DDPH) in Gulf of Iskenderun. Chemosphere, 16, 381-394.

SANTOS, R. H. A. 2015. Avaliação dos níveis de hidrocarbonetos na água e sedimentos do Canal de Santa Cruz-PE. Completion of Course Work - Bachelor of Biological/Environmental Sciences. Universidade Federal de Pernambuco.

SCHETTINI, C. A. F., PEREIRA, M. D., SIEGLE, E., MIRANDA, L. B. \& SILVA, M. P. 2013. Residual fluxes of suspended sediment in a tidally dominated tropical estuary. Continental Shelf Research, 70, 27-35.

SCHETTINI, C. A. F., MIRANDA, J. B., VALLE-LEVINSON, A., TRUCCOLO, E. C. \& DOMINGUES, E. C., 2016a. The circulation of the lower Capibaribe estuary (Brazil) and its implications for the transport of scalars. Brazilian Journal of Oceanography, 64, 3, 263-276. DOI: http://dx.doi. org/10.1590/S1679-87592016119106403

SCHETTINI, C. A. F., PAIVA, B. P., BATISTA, R. A. L., OLIVEIRA FILHO, J. C. \& TRUCCOLO, E. C. 2016b. Observation of an estuarine turbidity maximum in the highly impacted Capibaribe Estuary, Brazil. Brazilian Journal of Oceanography, 64, 185-190.

SCHETTINI, C. A. F. \& MIRANDA, L. B. 2010. Circulation and suspended particulate matter transport in a tidally dominated estuary: Caravelas Estuary, Bahia, Brazil. Brazilian Journal of Oceanography, 58, 1-11.

SCHETTINI, C. A. F., VALLE-LEVINSON, A. \& TRUCCOLO, E. C. 2017. Circulation and transport in short, low-inflow estuaries under anthropogenic stresses. Regional Studies in Marine Science, 10, 52-64.

SCHUBEL, J. R. \& CARTER, H. H. 1984. The estuary as a filter for fine grained suspended sediment. In: KENNEDY, V. S. (ed.) The estuary as a filter. New York: Academic Press.

SRH-PE (Secretaria de Recursos Hídricos do Estado de Pernambuco). 2010. Plano hidroambiental da bacia hidrográfica do Rio Capibaribe: Tomo I - diagnóstico hidroambiental. Recife: SRH-PE - Projetos Técnicos.

SUAPE. 2016. [Acessed 2016 Nov 14]. Available from: http:// www.suape.pe.gov.br/
TOLOSA, I., MORA, S., SHEIKHOLESLAMI, M. R., VILLENEUVE, J. P., BARTOCCI, J. \& CATTINI, C. 2004. Aliphatic and aromatic hydrocarbons in coastal Caspian Sea sediments. Marine Pollution Bulletin, 48, 44-60. DOI: http:// dx.doi.org/10.1016/S0025-326X(03)00255-8

WANG, X. C., ZHANG, Y. X. \& CHEN, R. F. 2001. Distribution and Partitioning of Polycyclic Aromatic Hydrocarbons (PAHs) in Different Size Fractions in Sediments from Boston Harbor, United States. Marine Pollution Bulletin, 42, 1139-1149. DOI: http://dx.doi.org/10.1016/S0025$-326 \mathrm{X}(01) 00129-1$

WATTAYAKORN, G., KING, B., WOLANSKI, E. \& SUTHANARUK, P. 1998. Seasonal dispersion of petroleum contaminants in the Gulf of Thailand. Continental Shelf Research, 18, 641-659.

WINTERWERP, J. C. \& VAN KESTEREN, W. G. M. 2004. Introduction to the physics of cohesive sediment dynamics in the marine environment. New York, Elsevier.

WOLANSKI, E. \& RIDD, P. 1986. Tidal mixing and trapping in mangrove swamps. Estuarine, Coastal and Shelf Science, $23,759-771$.

ZAGHDEN, H., KALLEL, M., ELLEUCH, B., OUDOT, J. \& SALIOT, A. 2007. Sources and distribution of aliphatic and polyaromatic hydrocarbons in sediments of Sfax, Tunisia, Mediterranean Sea. Marine Chemistry, 105, 70-89. DOI: http://dx.doi.org/10.1016/j.marchem.2006.12.016

ZANARDI, E., BÍCEGO, M. C., MIRANDA, L. B. \& WEBER, R. R. 1999a. Distribution and Origin of Hydrocarbons in Water and Sediment in São Sebastião, São Paulo, Brazil. Marine Pollution Bulletin, 38, 261-267.

ZANARDI, E., BÍCEGO, M. C. \& WEBER, R. R. 1999b. Dissolved/dispersed Petroleum Aromatic Hydrocarbons in the São Sebastião Channel, São Paulo, Brazil. Marine Pollution Bulletin, 38, 410-413.

ZANARDI-LAMARDO, E., BÍCEGO, M. C., CASTRO, B. M., MIRANDA, L. B. \& PRÓSPERI V. A. 2000. Southern Brazil. In: SHEPPARD, C. R. C. (Ed.). The Seas at Millennium: An environmental Evaluation. Volume 1. Chapter 47: 731-747. London: Pergamon Press 